\title{
Impact of 'Integrated Crop Management Approach' on Crop Yield and Economics in Amaravati and Yavatmal District (M.S.), India
}

\author{
Nandini Kelkar*, Bharat Kakade, Ravi Kote, Pramod Kumar Takawale \\ and Sandip Nighut
}

BAIF Development Research Foundation, Pune, 411052, India

*Corresponding author

\begin{abstract}
A B S T R A C T
Adverse climatic changes and increasing demand of agro produces are forcing abuse of natural and artificial resources resulting not only in deterioration of soil health but also reduction in crop yields. In addition, rainfed crops add to the adversity. In presence of these issues, to increase the yield of majorly grown crops in Yavatmal and Amaravati districts, an effort has been made by following sustainable and integrated crop management practices in two subsequent years i.e. 2016-17 and 2017-18. The practices had a great impact on crop yield and economics in case of pigeon pea, cotton, soybean, wheat and gram. For the year 2016-17 and 2017-18, in case of pigeon pea, cotton, soybean, wheat and gram the overall increase in yield per ha over conventional farming practices was 21.98 and $31.25 \%, 20.58$ and $30.00 \%, 22.86$ and $32.93 \%, 20.83$ and $30.35 \% 21.55$ and $33.99 \%$, respectively. The increase in yield due to integrated crop management approach resulted in additional income of 28.98 and $39.57 \%$ in case of pigeon pea, 40.93 and $42.07 \%$ in case of cotton, $36.16 \%$ and $79.54 \%$ in case of soybean, 56.42 and $55.00 \%$ in case of wheat and 28.25 and $28.34 \%$ in case of gram in the year 2016-17 and 2017-18, respectively. The outcome of the study indicated that there is need of awareness amongst farmer community for adopting integrated approach of crop management and a great scope for implementation of integrated, sustainable and holistic approach for crop production in future.
\end{abstract}

\section{Keywords}

crop yield, net income, integrated crop management approach

\section{Article Info}

Accepted:

14 May 2020

Available Online:

10 June 2020

\section{Introduction}

Climate change issues and growing demands of increasing population are forcing agriculture to produce more food from less available area of land. This is ultimately creating burden on use of natural resources. It has also resulted in increased use of chemical inputs for production, soil degradation issues and reduction in crop yield (Kumar and Gautam, 2014). India has 54\% rainfed land and $44 \%$ irrigated land.
Rainfed agriculture is characterized by water scarcity, land degradation, low inputs use and low productivity. Increment in area under irrigated land has also many limitations (Wani et al., 2017).

Thakare et al., (2016) from his study attempted for understanding and analyzing sustainability requirements in agriculture for Vidarbha region. In the region more numbers of farmers have committed suicide to overcome the miseries due to various reasons 
viz. nonproduction of crops, bad debts, drought, lack of markets, marketing and irrigation facilities, exploitation by private money lenders and other social and family causes. The data from various sources related to crop yield and rainfall in the region from past few years showed reduction in case of yield and irregular pattern and low rainfall intensity. Adoption of integrated crop management practices can be a solution for aforesaid problems up to some extent. By considering these facts and approach, the current study was conducted.

\section{Materials and Methods}

\section{Location, climate and agriculture}

The study was performed during 2016-17 and 2017-18 by implementing, crop specific integrated management practices for pigeon pea, cotton, wheat, soybean and gram. The targeted locations were Ralegaon and Kalamb blocks of Yavatmal district and Morshi block from Amaravati district. The study was conducted in total 14 selected villages from all the three blocks in both Kharif as well as Rabi season.

Amaravati district is located at longitude $21.1162{ }^{0} \mathrm{~N}$ and latitude $77.6536{ }^{0} \mathrm{E}$ while Yavatmal district at longitude $20.3888{ }^{\circ} \mathrm{N}$ and latitude $78.1204{ }^{0} \mathrm{E}$. The average annual rainfall in both the districts ranged from 600 $\mathrm{mm}$ to $1095 \mathrm{~mm}$ rainfall and was not uniform in all parts of the district. The rainfall pattern was irregular in both the districts. The climate of the districts is hot and dry with moderately cold winters. The major crops grown in the districts are cotton, soybean, pigeon pea, wheat and gram. The type of the soil in the districts is mainly black (Anonymous, 2015).

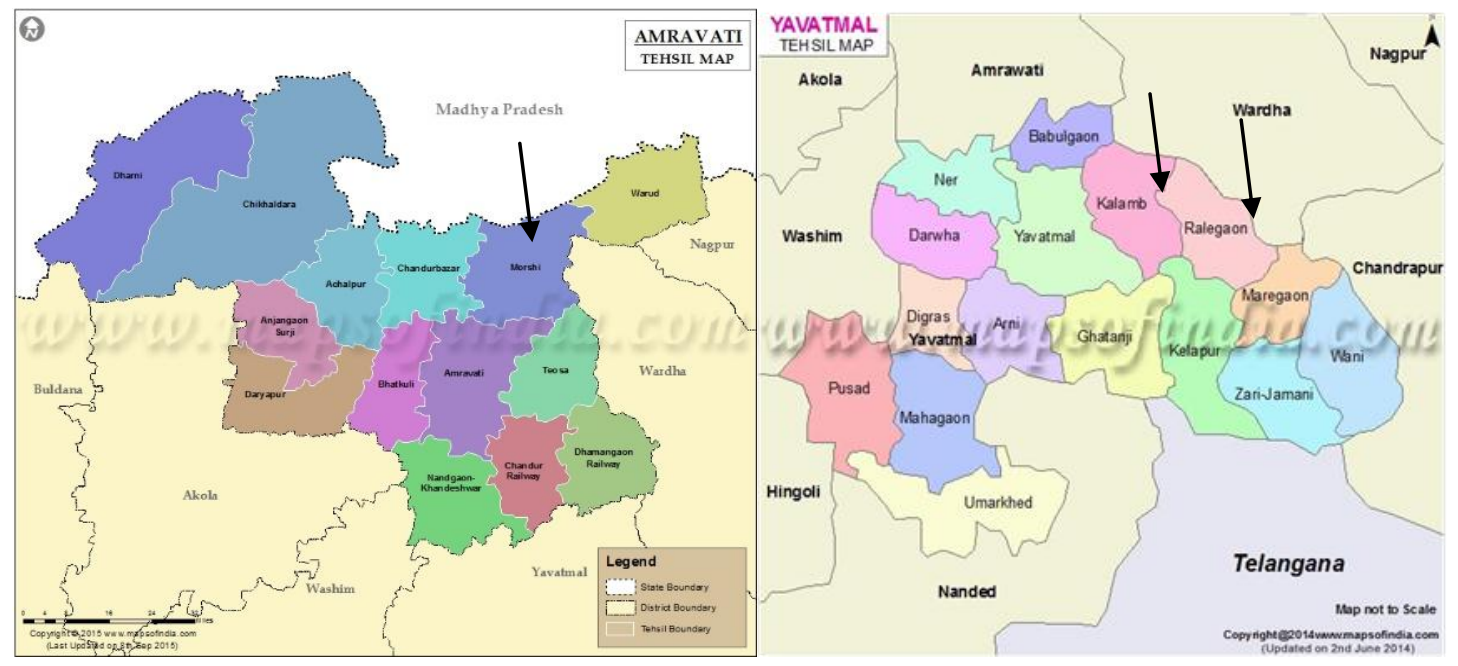

\section{Trial details}

To observe the effect of integrated crop management practices on crop yield and economics, demonstration plots along with control plots each of 0.40 ha area were established for each crop. The no of plots were 40 for pigeon pea, cotton and soybean each while 20 each for wheat and gram under study. By considering climatic conditions, water availability, crop requirements, a set of few practices were introduced for each crop and implemented for demo plots while control plot was maintained with farmers' traditional practices. In the region, cropping system of cotton as main crop and intercropped with pigeon pea is followed. Cotton, pigeon pea and soybean were majorly grown under rain 
fed conditions in kharif followed by wheat and gram in rabi provided with irrigation. Though the said crops are under irrigation, due to low rainfall and water scarcity in the region, available irrigation water did not match crop water requirement in both the years. .

The integrated crop management practices adopted for demonstration plots are described below. These practices were not followed by farmers previously.

Use of fertilizers as per soil test reports: Soil samples were tested before start of the experiment. As per soil test reports macro and micro nutrients were supplied by application of fertilizers at right time and in appropriate quantities through soil as well as foliar application.

Recommended seed rate: The recommended seed rate as per crop variety was adopted.

Seed treatment with bio fungicide and biofertlizers: Seeds were treated with bio fungicide (Trichoderma) and crop specific bio fertilizers like Rhizobium, Azotobactor, Azpsprillium, Phosphate Solubilising Bacteria (PSB).

Application of organic inputs: Application of vermicompost treated with beneficial soil microbes, jivamrut, and vermiwash were the organic sources of nutrients. Vermicompost, jivamrut and vermiwash were prepared on field.

Integrated pest disease management approach: For efficient pest and disease management, the integrated approach was adopted. The management practices included use of dashparni ark, neem oil, crop specific pheromone traps and sticky traps, trap crops, Metarhizium, Verticillium species, pesticides and fungicides in lower concentration only at the time of severe infestation etc.

Sowing method: Use of improved sowing methods like Broad Bed Furrow (BBF) in soybean and wheat, Ridge and Furrow method in cotton and maintenance of crop spacing in gram for optimum plant population.

\section{Data collection and statistical analysis}

The yield and net income data were recorded for all crops both in demo and control plots. The data of demo and control plots were compiled and compared statistically by using $\mathrm{z}$ test assuming equal variance.

\section{Results and Discussion}

The crop wise and year wise data on yield and economics is presented in tabulated form as well as in Fig. The data of pigeon pea yield and economics for 2016-17 and 2017-18 is presented in Table-1 and Fig-1. The data presented in Table no. 1 and depicted in Fig. no. 1 indicated that the yield in demo plot was $5.81 \mathrm{q} / \mathrm{ha}$ in 2016-17 and $5.25 \mathrm{q} / \mathrm{ha}$ in 201718 in pigeon pea. For control plots, the recorded yield was $4.78 \mathrm{q} / \mathrm{ha}$ in 2016-17 and $4.00 \mathrm{q} / \mathrm{ha}$ in 2017-18. The increase in yield for in demonstration plots over control plots was $21.98 \%$ in $2016-17$ and in $2017-18$, it was $31.25 \%$. In case of net income per ha, it was observed as Rs.9498 and Rs.7173 in control plots in the year 2016-17 and 201718 , respectively. The demo plot showed the net income of Rs.2251 per ha in the year 2016-17 and Rs.10013 per ha in the year 2017-18. For pigeon pea, in 2016-17, 28.98\% increase in net income was achieved over control while for the year 2017-18, it was $39.57 \%$. The significant increase in yield levels and net incomefor pigeon pea might be due to integrated approach over farmers' practices. The results are in conformity with Chaudhary et al., (2006). The data related with yield and economics in case of cotton for 2016-17 and 2017-18 is tabulated in Table-2 and graphically presented in Fig-2. 
In case of cotton, the yield levels for demo plots in 2016-17 and 2017-18 were 15.38 q/ha and $14.96 \mathrm{q} / \mathrm{ha}$, respectively. The control plots showed $12.75 \mathrm{q} /$ ha yield in 2016-17 and 11.50 $\mathrm{q} / \mathrm{ha}$ in 2017-18. The demo plots had significantly higher yields in both the years. In 2016-17, the increase in yield was recorded as $20.58 \%$ and in $2017-18$ it was $30.00 \%$. The results are in conformity with Chaudhary et al., (2006), Ushanandini et al., (2017) and Gudhade et al., (2015).

The data also showed the values for net income per ha as Rs.38879 and Rs.33369 respectively, in the year 2016-17 and 2017-18 for demo plots. The control plot had net income of Rs.27586 in the year 2016-17 and Rs.23487 in the year 2017-18.For cotton, $40.93 \%$ and $42.07 \%$ increase in net income was achieved in 2016-17 and 2017-18, respectively. Similar findings were reported by Vora et al., (2015). The reason for increase in net income and yield in case of demo plot may be attributed to use of integrated crop management practices. The data of yield and economics in soybean crop for 2016-17 and 2017-18 is given in Table-3 and illustrated in Fig-3. From Table no. 3 and Fig. no. 3, it was observed that demo plot in soybean had higher yields in both the years than control which were 16.53 and $11.00 \mathrm{q} / \mathrm{ha}$ in 2016-17 and 2017-18, respectively. The control plots recorded $13.44 \mathrm{q} /$ ha yield in 2016-17 and 8.28 $\mathrm{q} / \mathrm{ha}$ in 2017-18. The increase in yield in 2016-17 was $22.86 \%$ and $32.93 \%$ in $2017-18$. Further, it was found that the demo plot also showed high net income than control in the year 2016-17 as well as in the year 2017-18. The respective figures of net income per ha were Rs.18315 and Rs.6465 in case of control plot while for demo plot those were Rs.24940 and Rs.11607. Increase in net income by $36.16 \%$ and $79.54 \%$ in $2016-17$ and $2017-18$, respectively was noted in soybean crop. Due to dry spell in the month of July during 201718 yield significantly hampered in case of demo as well as control plots. Due to integrated practices demo plot still recorded significantly higher yield and net income than control. Ghodke et al., (2018) also observed increase in yield through following integrated management practices in case of soybean. The results related with net income were comparable to those reported by Wani et al., (2017) from their study.

The data related with yield and economics in case of wheat for 2016-17 and 2017-18 is tabulated in Table-4 and depicted in Fig-4. The data from Table no. 4 and Fig no. 4 revealed that the yield of wheat was 14.51 and $16.75 \mathrm{q} / \mathrm{ha}$ in 2016-17 and 2017-18, respectively for demo plots. However, for control plots the yields were 11.99 and 12.86 q/ha in 2016-17 and 2017-18, respectively. The demo plot gave $20.83 \%$ higher yield in 2016-17 and $30.35 \%$ in $2017-18$ over control plot. Gawali and Unni (2018) and Ugale Nitin (2014) also recorded higher yield in case of wheat due to adoption of integrated crop management practices. Further, from the data, it was observed that the control plot showed net income per ha of Rs.5083 in the year 2016-17 and Rs.5570 in the year 2017-18. For the demo plot, its values per ha were Rs.8201 and Rs.8633 in the year 2016-17 and 2017-18, respectively. In case of wheat, an improvement of net income in 2016-17 was $56.42 \%$ while in $2017-18$ it was $55.00 \%$.

The integrated management approach may be responsible for significant increase in net income for both the years over farmers' practices. Various workers namely Singh et al., (2019) and Kumar et al., (2017)were reported similar findings from their research trials.

The data of yield and economics of gram for 2016-17 and 2017-18 is presented in Table-5 and Fig-5. For gram, in 2016-17 and 2017-18, the yield values were 12.13 and 
$13.50 \mathrm{q} / \mathrm{ha}$, respectively for demo plot. In case of control plot, the recorded yields were 9.98 q/ha in 2016-17 and 10.07 q/ha in 2017-18. The increase in yield due to integrated approach was $21.55 \%$ in 2016-17 and $33.99 \%$ in 2017-18. In case of gram, integrated approach might be resulted in higher yields in both the years over traditional approach. The data also showed higher values of net income for demo plots over control. Net income of Rs.23506 and Rs.29375 were the values per ha in the year 2016-17 and 2017-18, respectively for control plot. The respective figures of net income per ha for the year 2016-17 and 2017-18 were Rs.30149 and Rs.37707 in case of demo plot.

The net income increased by $28.25 \%$ in 201617 and $28.36 \%$ in 2017-18 for gram. In case of gram, the observations related with yields are in conformity with Nemade et al., (2017) while the results related with net income were comparable to those recorded by Wani et al., (2017).

Table.1 Crop: Pigeon Pea

\begin{tabular}{|c|c|c|c|c|c|c|c|c|}
\hline \multirow{3}{*}{$\begin{array}{c}\text { z-Test: Two- } \\
\text { Sample } \\
\text { Assuming Equal } \\
\text { Variances }\end{array}$} & \multicolumn{4}{|c|}{ Yield (q/ha) } & \multicolumn{4}{|c|}{ Net income (Rs/ha) } \\
\hline & \multicolumn{2}{|c|}{ 2016-17 } & \multicolumn{2}{|c|}{ 2017-18 } & \multicolumn{2}{|c|}{ 2016-17 } & \multicolumn{2}{|c|}{ 2017-18 } \\
\hline & Control & Demo & Control & Demo & Control & Demo & Control & Demo \\
\hline Mean & 4.78 & 5.81 & 4.00 & 5.25 & 9498 & 12251 & 7173 & 10013 \\
\hline Observations & 40 & 40 & 40 & 40 & 40 & 40 & 40 & 40 \\
\hline $\begin{array}{l}\text { Hypothesized } \\
\text { Mean Difference }\end{array}$ & 0 & & 0 & & 0 & & 0 & \\
\hline df & 78 & & 78 & & 78 & & 78 & \\
\hline$P(T<=t)$ two-tail & $5.85^{-06 * *}$ & & $4.71^{-10^{\text {*** }}}$ & & $6.69^{-69 * *}$ & & $3.70^{-51 * *}$ & \\
\hline CV $(\%)$ & 21.12 & 14.97 & 20.25 & 11.04 & 13.06 & 10.28 & 20.77 & 14.00 \\
\hline
\end{tabular}

*Significant at 5\%,**highly significant at $1 \%$

Table.2 Crop: Cotton

\begin{tabular}{|c|c|c|c|c|c|c|c|c|}
\hline \multirow{3}{*}{$\begin{array}{l}\text { z-Test: Two- } \\
\text { Sample } \\
\text { Assuming Equal } \\
\text { Variances }\end{array}$} & \multicolumn{4}{|c|}{ Yield (q/ha) } & \multicolumn{4}{|c|}{ Net income $($ Rs/ha) } \\
\hline & \multicolumn{2}{|c|}{ 2016-17 } & \multicolumn{2}{|c|}{ 2017-18 } & \multicolumn{2}{|c|}{ 2016-17 } & \multicolumn{2}{|c|}{ 2017-18 } \\
\hline & Control & Demo & Control & Demo & Control & Demo & Control & Demo \\
\hline Mean & 12.75 & 15.38 & 11.50 & 14.96 & 27586 & 38879 & 23487 & 33369 \\
\hline Observations & 40 & 40 & 40 & 40 & 40 & 40 & 40 & 40 \\
\hline $\begin{array}{l}\text { Hypothesized } \\
\text { Mean Difference }\end{array}$ & 0 & & 0 & & 0 & & 0 & \\
\hline df & 78 & & 78 & & 78 & & 78 & \\
\hline$P(T<=t)$ two-tail & $1.44^{-09 * *}$ & & $1.69^{-10 * *}$ & & $6.58^{-25 * *}$ & & $8.50^{-21 * *}$ & \\
\hline $\mathrm{CV}(\%)$ & 15.17 & 9.48 & 18.34 & 14.03 & 11.76 & 8.81 & 15.08 & 10.12 \\
\hline
\end{tabular}

*Significant at 5\%,**highly significant at $1 \%$ 
Table.3 Crop: Soybean

\begin{tabular}{|c|c|c|c|c|c|c|c|c|}
\hline \multirow{3}{*}{$\begin{array}{l}\text { z-Test: Two- } \\
\text { Sample Assuming } \\
\text { Equal Variances }\end{array}$} & \multicolumn{4}{|c|}{ Yield (q/ha) } & \multicolumn{4}{|c|}{ Net income (Rs/ha) } \\
\hline & \multicolumn{2}{|c|}{ 2016-17 } & \multicolumn{2}{|c|}{ 2017-18 } & \multicolumn{2}{|c|}{ 2016-17 } & \multicolumn{2}{|c|}{ 2017-18 } \\
\hline & Control & Demo & Control & Demo & Control & Demo & Control & Demo \\
\hline Mean & 13.44 & 16.53 & 8.28 & 11.00 & 18315 & 24940 & 6465 & 11607 \\
\hline Observations & 40 & 40 & 40 & 40 & 40 & 40 & 40 & 40 \\
\hline $\begin{array}{l}\text { Hypothesized } \\
\text { Mean Difference }\end{array}$ & 0 & & 0 & & 0 & & 0 & \\
\hline df & 78 & & 78 & & 78 & & 78 & \\
\hline $\mathbf{P}(\mathrm{T}<=\mathbf{t})$ two-tail & $4.59^{-08 * *}$ & & $7.56^{-09 * *}$ & & $4.76^{-33 * *}$ & & $1.05^{-45^{* *}}$ & \\
\hline CV $(\%)$ & 17.26 & 13.49 & 19.80 & 17.63 & 8.97 & 4.91 & 9.77 & 7.18 \\
\hline
\end{tabular}

$*$ Significant at $5 \%, * *$ highly significant at $1 \%$

Table.4 Crop: Wheat

\begin{tabular}{|c|c|c|c|c|c|c|c|c|}
\hline \multirow{3}{*}{$\begin{array}{l}\text { z-Test: Two- } \\
\text { Sample Assuming } \\
\text { Equal Variances }\end{array}$} & \multicolumn{4}{|c|}{ Yield (q/ha) } & \multicolumn{4}{|c|}{ Net income (Rs/ha) } \\
\hline & \multicolumn{2}{|c|}{ 2016-17 } & \multicolumn{2}{|c|}{ 2017-18 } & \multicolumn{2}{|c|}{ 2016-17 } & \multicolumn{2}{|c|}{ 2017-18 } \\
\hline & Control & Demo & Control & Demo & Control & Demo & Control & Demo \\
\hline Mean & 11.99 & 14.51 & 12.86 & 16.75 & 5083 & 8201 & 5570 & 8633 \\
\hline Observations & 20 & 20 & 20 & 20 & 20 & 20 & 20 & 20 \\
\hline $\begin{array}{l}\text { Hypothesized } \\
\text { Mean Difference }\end{array}$ & 0 & & 0 & & 0 & & 0 & \\
\hline df & 38 & & 38 & & 38 & & 38 & \\
\hline$P(T<=t)$ two-tail & $4.75^{-12 * *}$ & & $4.07^{-09 * *}$ & & $3.34^{-17^{* *}}$ & & $1.61^{-12^{* *}}$ & \\
\hline CV $(\%)$ & 11.17 & 7.78 & 11.97 & 10.08 & 16.20 & 10.99 & 18.57 & 13.37 \\
\hline
\end{tabular}

* Significant at $5 \%$,**highly significant at $1 \%$

Table.5 Crop: Gram

\begin{tabular}{|c|c|c|c|c|c|c|c|c|}
\hline \multirow{3}{*}{$\begin{array}{l}\text { z-Test: Two- } \\
\text { Sample } \\
\text { Assuming Equal } \\
\text { Variances }\end{array}$} & \multicolumn{4}{|c|}{ Yield (q/ha) } & \multicolumn{4}{|c|}{ Net income (Rs/ha) } \\
\hline & \multicolumn{2}{|c|}{ 2016-17 } & \multicolumn{2}{|c|}{ 2017-18 } & \multicolumn{2}{|c|}{ 2016-17 } & \multicolumn{2}{|c|}{ 2017-18 } \\
\hline & Control & Demo & Control & Demo & Control & Demo & Control & Demo \\
\hline Mean & 9.98 & 12.13 & 10.07 & 13.50 & 23506 & 30149 & 29375 & 37707 \\
\hline Observations & 20 & 20 & 20 & 20 & 20 & 20 & 20 & 20 \\
\hline $\begin{array}{l}\text { Hypothesized } \\
\text { Mean Difference }\end{array}$ & 0 & & 0 & & 0 & & 0 & \\
\hline df & 38 & & 38 & & 38 & & 38 & \\
\hline$P(T<=t)$ two-tail & $8.30^{-08 * *}$ & & $8.17^{-15 * *}$ & & $5.47^{-23}$ ** & & $1.20^{-25}$ *** & \\
\hline CV $(\%)$ & 19.63 & 13.68 & 15.49 & 10.37 & 13.03 & 10.75 & 14.24 & 11.56 \\
\hline
\end{tabular}

*Significant at $5 \%, * *$ highly significant at $1 \%$ 


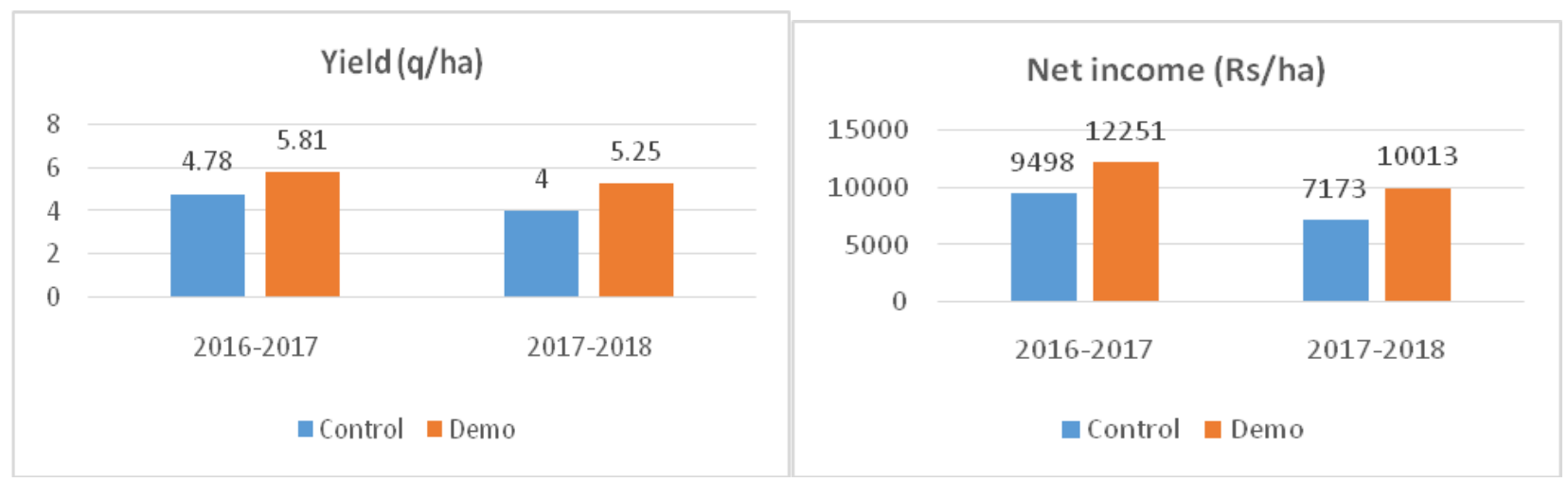

Fig.1 Crop: Pigeon Pea

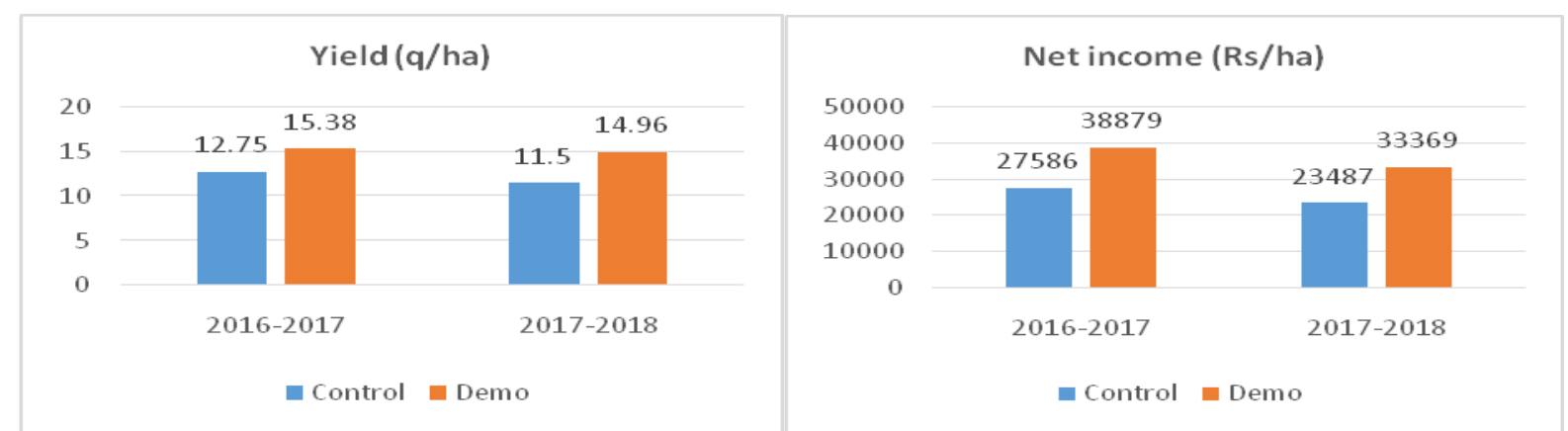

Fig.2 Crop: Cotton

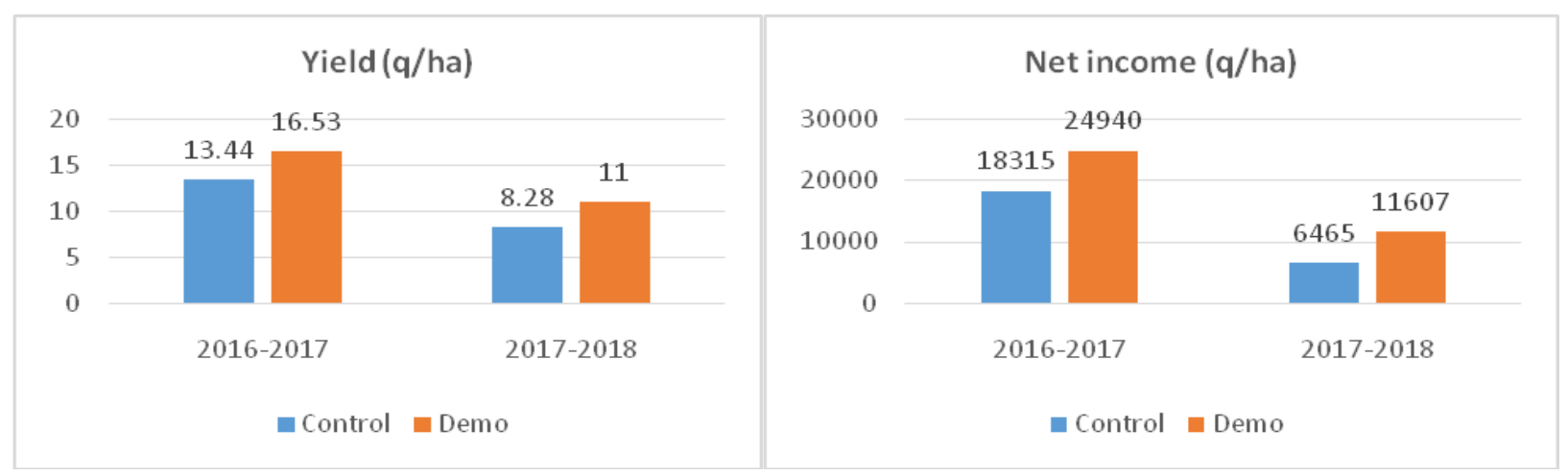

Fig.3 Crop: Soybean

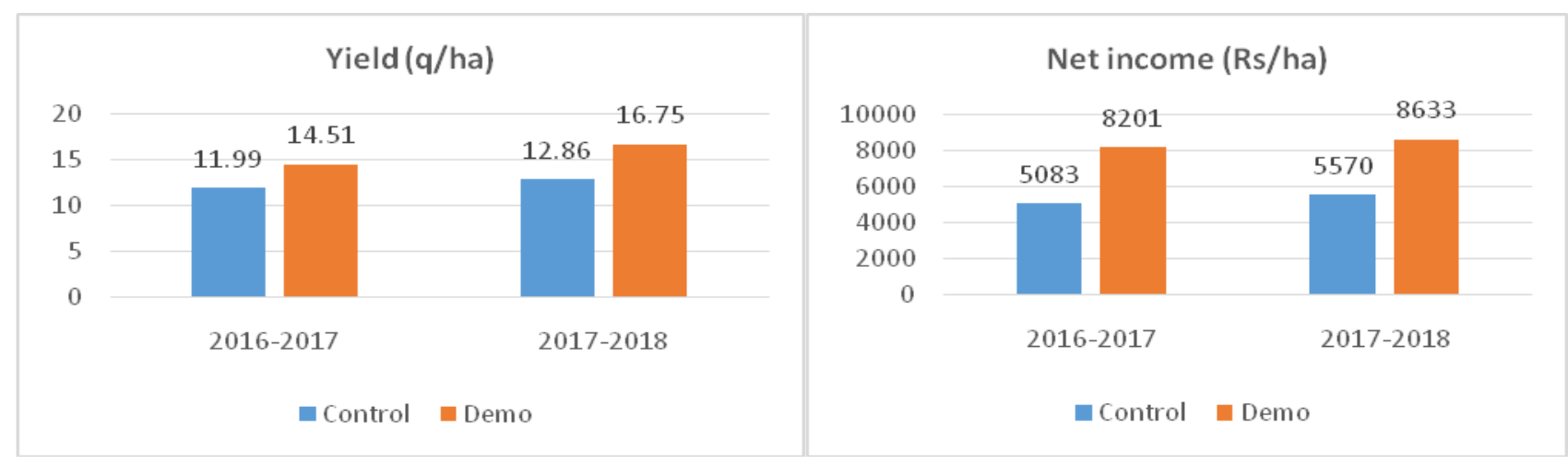

Fig.4 Crop: Wheat 


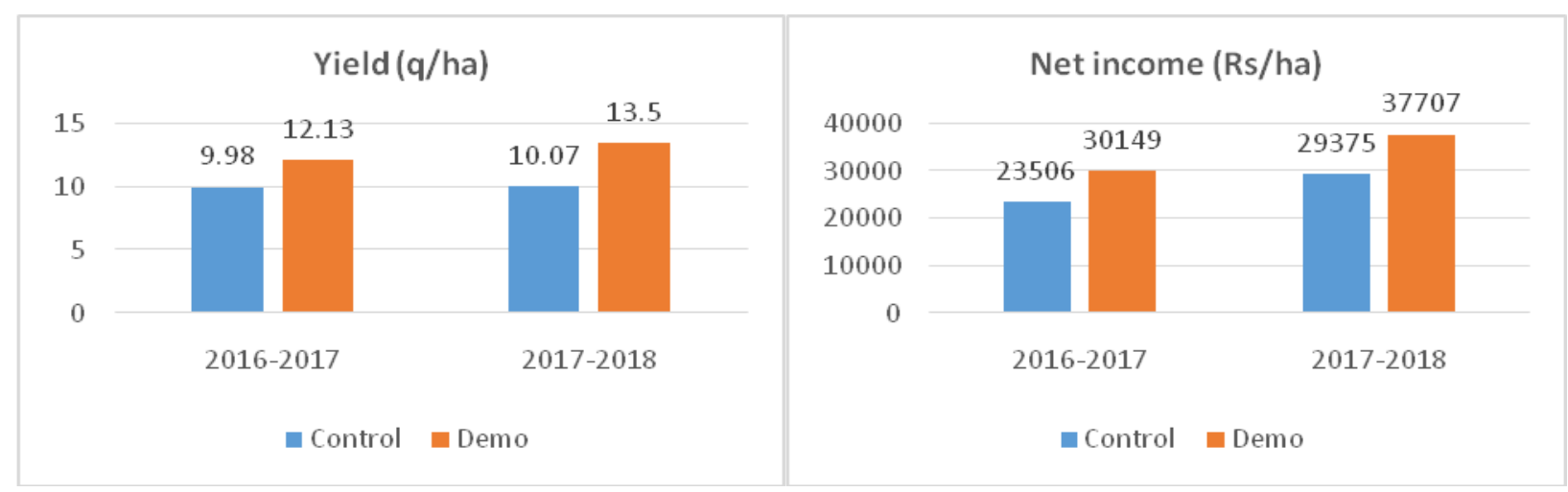

Fig.5 Crop: Gram

Significant increase in yield and net income per ha was achieved in all the crops under study due to demonstration of integrated management approach in Yavatmal and Amravati district. The results suggested for improvement in farmers' practices to achieve greater yield and thus total income in the region.

From present study it can be concluded that there is a great scope for implementation of integrated, sustainable and holistic approach for crop production in future. For successful implementation, awareness amongst farmer community for adopting integrated approach for crop management is needed.

\section{Acknowledgement}

This work of integrated crop management trials was a part of the project titled "Soil Protection and Rehabilitation for Food Security in India" (ProSoil) implemented by GIZ (Deutsche Gesellschaft fur Internationale Zusammenarbeit), Germany) commissioned by the German Federal Ministry for Economic Cooperation and Development (BMZ).

The activities referred in the article were undertaken within the framework of ProSoil. NABARD (National Bank for Agriculture and Rural Development), Maharashtra Regional Office, India, monitored the project. We sincerely thank the support provided by the officials of GIZ and NABARD. We are grateful to the community with whom these trials were undertaken.

\section{References}

Anonymous (2015). Impact of BT cotton: a case study of Yavatmal district of Maharashtra state. Shodhganga.inflibnet.ac.in/bitstream/ 10603/21062/13/15_chapter\%206.pdf

Chaudhari, P.M., B Arun. Kambale, Raundal Pankaj U and Sanjay S.Chitodkar (2006). Effect of intercropping of pigeonpea, sorghum and cotton on productivity and yield advantages of soybean (Glycine max.L.) under rainfed condition. Internat. J. agric. Sci. 2 (2) :(478-479).

Gawali, R. and Unni Shila P.K. (2018). Integrated nutrient management approach on wheat (Triticum aestivum L.) in vertisols. Int.J.Curr.Microbiol.App.Sci 7(4): 3144-3153.

Ghodke, P.D., Madane A., Jagannath, and V.J. Takankhar (2018). Effect of integrated nutrient management on growth and yield of soybean (Glycine max L. Meril). International Journal of Chemical Studies. 6(4): 264-266.

Gudadhe, N.,Dhonde M.B. and. N.A.Hirwe. (2015). Effect of integrated nutrient 
management on soil properties under cotton chick pea cropping sequence in vertisols of deccan plateau of India. Indian J. Agric. Res. 49 (3): 207-214.

Kumar, R. and H.Gautam, (2014). Climate change and its impact on agricultural productivity in India. J. Climatol Weather Forecasting. 2 (1): 1-3.

Kumar, V., Kumar, T., Singh, G. and R. A. Singh (2017). Effect of integrated nutrient management on yield of rice and its residual effect on wheat in rice wheat system under low land. Annals of Plant and Soil Research.19(4): 360365.

Nemade Seema M., Ghorade R.B and. N.B. Mohod (2017). Integrated nutrient management (INM) in sorghum chickpea cropping system under unirrigated conditions. International Journal of Current Microbiology and Applied Sciences. 6 (2): 379-385.

Singh, V.K., Dwivedi, B.S., Mishra. R.P., Shukla, A.K., Timsina, J., Upadhyay, P.K., Shekhawat, K., Majumdar, K. and A. S. Panwar (2019). Yields, soil health and farm profits under a ricewheat system: long-term effect of fertilizers and organic manures applied alone and in combination. Agronomy. 9 (1): 1-22.

Thakare R. M., Kalpana R. and Thakare (Kawathekar) (2016). Agriculture practices sustainability in Vidarbha. IOSR Journal of Agriculture and Veterinary Science. 9 (7): 5-10.

Ugale N. (2014): Effect of different organic inputs with Jivamrut on yield, quality and soil properties in soybean wheat cropping sequence. Thesis submitted to Mahatma Phule Krishi Vidyapeeth, Rahuri, Ahmednagar, Maharashtra, India.

Ushanandini, V.S., T. Ramesh, B. Anil Kumar, Padmasri, A., Rao, K Jeevan. and J. Aruna Kumari (2017). Studies on INM practise on yield attributing characters incotton hybrid under high density planting system (HDPS). Bulletin of Environment, Pharmacology and Life Sciences.Special issue 6 (1):410-413.

Vora, V.D., Rakholiya, K.D., Rupapara, K.V., Sutaria G.S. and K.N. Akbari (2015). Effect of integrated nutrient management on Bt cotton and postharvest soil fertility under dry farming agriculture. Published at https://www.researchgate.net/publicati on/281289262.

Wani, S. P., Anantha, K.H. and K. K. Garg,(2017). Soil properties, crop yield and economics under integrated crop management practices in Karnataka, Southern India. World Development(93): 43-61.

\section{How to cite this article:}

Nandini Kelkar, Bharat Kakade, Ravi Kote, Pramod Kumar Takawale and Sandip Nighut. 2020. Impact of 'Integrated Crop Management Approach' on Crop Yield and Economics in Amaravati and Yavatmal District (M.S.), India. Int.J.Curr.Microbiol.App.Sci. 9(06): 185-193. doi: https://doi.org/10.20546/ijcmas.2020.906.025 